Kredo 4 (2021)
KREDO: Jurnal Ilmiah Bahasa dan Sastra
Terakreditasi Sinta 4 berdasarkan Keputusan
Direktorat Jenderal Penguatan Riset dan
Pengembangan, Kementerian Riset, Teknologi dan
Pendidikan Tinggi Republik Indonesia
Nomor: 23/E/KPT/2019.08 Agustus 2019
https://jurnal.umk.ac.id/index.php/kredo/index

\title{
EKSPERIMENTASI MODEL PEMBELAJARAN BERBASIS PROYEK UNTUK MENGOPTIMALKAN KEMAMPUAN MENULIS SISWA
}

\author{
Siti Suwadah Rimang ${ }^{1}$, Syafruddin ${ }^{2}$, Sitti Aida Azis ${ }^{3}$, Rosmini Madeamin ${ }^{4}$ \\ sitisuwadahrimang@unismuh.ac.id
}

Universitas Muhammadiyah Makassar, Indonesia

\begin{abstract}
Info Artikel
Sejarah Artikel

Diterima

3 Februari 2021

Disetujui

17 Maret 2021

Dipublikasikan

7 April 2021
\end{abstract}

\section{Keywords}

Exposition, and project-based learning

\section{Kata Kunci}

Eksposisi, pembelajaran berbasis proyek
: $\quad$ Abstract

- This research is an experimental study which aims to determine the effectiveness of the projectbased learning model in increasing the ability to write exposition text of the XI grade students of SMK Muhammadiyah 3 Makassar. The population in this study were students of SMK Muhammadiyah 3 Makassar for the 2018/2019 academic year. The sample in this study were students of class XIKPW SMK Muhammadiyah 3 Makassar consisting of 14 students with 14 female students and 0 male students. Data were collected using two instruments, namely a questionnaire for affective competence and a test of learning outcomes (cognitive) in Indonesian. The results of statistical analysis show that the results of learning Indonesian language students in class XIKPW SMK Muhammadiyah 3 Makassar are categorized moderate with an average score of 81 with a standard deviation of 2.68 from the ideal score of 100. From the results of the analysis above, it

: can be concluded that there is effectiveness between project-based learning in writing student exposition text on Indonesian language learning outcomes in class XI KPW SMK Muhammadiyah 3 Makassar.

\begin{abstract}
Penelitian ini merupakan penelitian eksperimen yang bertujuan untuk mengetahui keefektifan model pembelajaran berbasis proyek terhadap peningkatan kemampuan menulis teks eksposisi siswa Kelas XI SMK Muhammadiyah 3 Makassar. Populasi dalam penelitian ini adalah siswa SMK Muhammadiyah 3 Makassar tahun ajaran 2018/2019. Sampel dalam penelitian ini adalah siswa kelas XIKPW SMK Muhammadiyah 3 Makassar yang terdiri dari 14 siswa dengan 14 siswa perempuan dan 0 siswa laki-laki. Pengambilan data dilakukan dengan menggunakan dua instrumen, yaitu angket kompetensi afektif dan tes hasil belajar (kognitif) bahasa Indonesia. Hasil analisis statistika menunjukkan bahwa hasil belajar bahasa Indonesia siswa kelas XIKPW SMK Muhammadiyah 3 Makassar dikategorikan sedang dengan skor rata-rata 81 dengan standar deviasi 2,68 dari skor ideal 100. Dari hasil analisis di atas maka dapat disimpulkan terdapat keefektifan antara pembelajaran berbasis proyek dalam menulis teks eksposisi siswa terhadap hasil belajar bahasa Indonesia kelas XI KPW SMK Muhammadiyah 3 Makassar.
\end{abstract}




Kredo 4 (2021)
KREDO: Jurnal Ilmiah Bahasa dan Sastra
Terakreditasi Sinta 4 berdasarkan Keputusan
Direktorat Jenderal Penguatan Riset dan
Pengembangan, Kementerian Riset, Teknologi dan
Pendidikan Tinggi Republik Indonesia
Nomor: 23/E/KPT/2019. 08 Agustus 2019
https://jurnal.umk.ac.id/index.php/kredo/index

\section{PENDAHULUAN}

Bahasa merupakan sarana komunikasi yang memegang peranan sangat penting dalam kehidupan manusia, terutama sebagai alat ekspresi diri, alat integrasi serta alat adaptasi dan kontrol sosial. Dengan kata lain, sebagai alat komunikasi, bahasa dapat dipergunakan sebagai sarana untuk menjalin kerjasama dengan pihak lain, baik untuk kepentingan bersama maupun untuk kepentingan perorangan. Disamping itu, bahasa dapat dipergunakan untuk bertukar pendapat, berdiskusi atau membahas suatu persoalan yang dihadapi.

Sebagai ekspresi diri, bahasa adalah untuk mengungkapkan gagasan, pikiran, perasaan dan pengalaman yang dimiliki sebagai alat integrasi dan adaptasi sosial, bahasa memungkinkan setiap penutur merasa terikat dengan kelompok masyarakat yang menggunakan bahasa yang sama. Sebagai kontrol sosial bahasa dapat digunakan untuk mengatur, merencanakan, menganalisis dan mengevaluasi berbagai aktifitas sosial (Martaulina, 2018).

Menurut Noermanzah

(2019)

bahwa bahasa komunikasi sebagai suatu proses, melibatkan (1) pihak yang berkomunikasi, (2) informasi yang dikomunikasikan, dan (3) alat komunikasi. Sejalan dengan pendapat ini Wicaksono and Roza (2015) mengungkapkan bahwa dalam komunikasi, bahasa harus mampu menampung perasaan yang pemikiran pemakainya, serta mampu menimbulkan adanya saling memahami antara pembicara dan pendengar dalam suatu pembicaraan. Menulis memerlukan keterampilan karena diperlukan latihanlatihan yang berkelanjutan dan terusmenerus terutama dalam mata pelajaran Bahasa Indonesia yang mencakup aspek kemampuan yaitu keterampilan menyimak, keterampilan berbicara, keterampilan membaca, dan keterampilan menulis.

Dengan menulis, seorang akan menempuh seluruh proses dalam berbahasa. Sebelum menulis, ia dituntut untuk menyimak, berbicara, dan membaca dengan baik. Demikian pula halnya dengan siswa, agar mampu menulis dengan baik ia dituntut mampu menyimak dengan baik setiap materi pelajaran yang disampaikan oleh guru. Ia harus mampu mengkomunikasikan kembali hasil penyimakkannya terhadap materi dengan bahasa lisan. Ia juga dituntut untuk membaca referensi terkait dengan apa yang akan ditulisnya.

Kebutuhan yang besar terhadap penguasaan keterampilan menulis tersebut tidak sejalan dengan minat dan motivasi siswa untuk dapat menguasai 


Kredo 4 (2021)
KREDO: Jurnal Ilmiah Bahasa dan Sastra
Terakreditasi Sinta 4 berdasarkan Keputusan
Direktorat Jenderal Penguatan Riset dan
Pengembangan, Kementerian Riset, Teknologi dan
Pendidikan Tinggi Republik Indonesia
Nomor: 23/E/KPT/2019. 08 Agustus 2019
https://jurnal.umk.ac.id/index.php/kredo/index

keterampilan menulis dengan baik. Fakta di lapangan menunjukkan bahwa keterampilan menulis siswa masih rendah, lebih khusus keterampilan menulis teks eksposisi. Hal ini dibuktikan dengan masih jarangnya karya-karya siswa tentang menulis teks eksposisi dari beberapa sekolah menengah kejuruan (SMK) yang peneliti amati, khususnya di SMK Muhammadiyah 3 Makassar. Di sisi lain, nilai-nilai tes kemampuan menulis teks eksposisi siswa juga masih rendah.

Permasalahan di atas, sangatlah wajar terjadi karena kurangnya motivasi dari guru dan dari diri siswa sendiri untuk menguasai keterampilan menulis teks eksposisi. Dengan minimnya motivasi tersebut membuat siswa enggan untuk membiasakan diri dalam menulis. Pada akhirnya, karena tidak terbiasa dalam menulis menyebabkan siswa kesulitan dalam menuangkan ide-ide dan gagasannya dalam sebuah tulisan.

Menyadari kelemahan tersebut diperlukan sebuah inovasi untuk membantu siswa dalam meningkatkan keterampilan menulis yang mereka miliki. Oleh karena itu, dalam pembelajaran bahasa khususnya pembelajaran keterampilan menulis, dibutuhkan perbaikan yang dapat mendorong siswa secara keseluruhan agar aktif menulis. Adapun upaya yang dapat dilakukan untuk meningkatkan kualitas proses dan hasil belajar yaitu dengan model pembelajaran berbasis proyek.

\section{KAJAN TEORI}

\section{A. Teori Pembelajaran Keterampilan} Menulis

\section{Pengertian Menulis}

Menulis merupakan keterampilan mekanis yang dapat dipahami dan dipelajari. Menulis termasuk kegiatan produktif yang dilakukan secara terus menerus dan berulang ulang (rekursif). (Gie 2002) berpendapat bahwa menulis adalah keseluruhan rangkaian kegiatan seseorang mengungkapkan buah pikirannya melalui bahasa tulis untuk dibaca dan dimengerti oleh orang lain.

\section{Tujuan Menulis}

Menulis digunakan orang terpelajar untuk berbagai tujuan seperti mencatat, merekam, meyakinkan, memberitahu, dan memengaruhi. Hugo Hartig (dalam Djuroto, Setokoesoemo, and Suprijadi 2013) merangkum tujuan penulisan sebagai berikut:

a. Tujuan penugasan. Pada tujuan ini, sebenarnya penulis menulis sesuatu karena ditugasi.

b. Tujuan alturistik. Penulis bertujuan mengenakan, menghindarkan kedukaan, ingin menolong para pembaca memahami, menghargai 


Kredo 4 (2021)
KREDO: Jurnal Ilmiah Bahasa dan Sastra
Terakreditasi Sinta 4 berdasarkan Keputusan
Direktorat Jenderal Penguatan Riset dan
Pengembangan, Kementerian Riset, Teknologi dan
Pendidikan Tinggi Republik Indonesia
Nomor: 23/E/KPT/2019. 08 Agustus 2019
https://jurnal.umk.ac.id/index.php/kredo/index

perasaan, ingin membuat hidup para pembaca lebih mudah dan menyenangkan.

c. Tujuan persuasif. Penulis bertujuan meyakinkan para pembaca akan kebenaran yang diutarakan.

d. Tujuan penerangan. Penulis bertujuan memberikan informasi atau keterangan penerangan dalam pembaca.

e. Tujuan pernyataan diri. Penulis bertujuan memperkenalkan atau menyatakan diri kepada pembaca melalui tulisannya, pembaca dapat memahami sang penulis.

f. Tujuan kreatif. Penulis bertujuan agar para pembaca dapat memiliki nilai artistik atau nilai kesenian.

g. Tujuan pemecahan masalah. Dalam tulisan ini, penulis berusaha memecahkan suatu masalah yang dihadapi.

\section{Teknik Menulis yang Baik}

a. Kalimat rata-rata pendek. Tetapi jangan sering memunculkan kalimat yang terus terusan pendek, karena dapat membuat pembaca bosan.

b. Pilih kata dan kalimat sederhana. Bentuk kompleks boleh, tapi jika ada pilihan, pilihlah yang sederhana.

c. Pilih kata-kata yang lazim. Sebagai penyampai pesan, penulis harus menghubungkan pikirannya dengan pengalaman orang lain. d. Hindari kata-kata yang tidak perlu.

e. Beri kekuatan kata kerja. Kata kerja aktif yang kuat dalam penulisan memberikan lonjakan menahan perhatian pembaca. Kalimat aktif lebih langsung dan kuat daripada kalimat pasif.

f. Gunakan gaya bertutur, seperti Anda berbicara. Hindari bahasa formal yang kaku.

g. Gunakan istilah yang bisa digambarkan oleh pembaca. Kita tidak boleh berasumsi semua pembaca tahu.

\section{Manfaat Menulis}

Menurut Dalman (2021) manfaat menulis ada delapan, diantaraya:

a. Mengetahui kemampuan dan potensi diri serta pengetahuan kita tentang topik yang dipilihnya.

b. Lebih banyak menyerap, mencari, serta menguasai informasi sehubungan dengan topik yag ditulis.

c. Menulis berarti mengorganisasi gagasan secara sistematik serta mengungkapkan secara tersurat.

d. Lebih mudah memecahkan masalah dengan menganalisisnya secara tersurat dalam konteks yang lebih konkret.

e. Dengan menulis kita aktif berpikir sehingga kita dapat menjadi penemu sekaligus pemecah masalah, bukan sekedar penyadap informasi. 


Kredo 4 (2021)
KREDO: Jurnal Ilmiah Bahasa dan Sastra
Terakreditasi Sinta 4 berdasarkan Keputusan
Direktorat Jenderal Penguatan Riset dan
Pengembangan, Kementerian Riset, Teknologi dan
Pendidikan Tinggi Republik Indonesia
Nomor: 23/E/KPT/2019.08 Agustus 2019
https://jurnal.umk.ac.id/index.php/kredo/index

f. Kegiatan menulis yang terencana akan membiasakan kita berpikir dan berbahasa secara tertib.

\section{B. Pengertian Model Pembelajaran}

Model pembelajaran adalah suatu perencanaan atau suatu pola yang digunakan sebagai pedoman dalam merencanakan pembelajaran di kelas. Model pembelajaran mengacu pada pendekatan pembelajaran yang akan digunakan, termasuk di dalamnya tujuan-tujuan pengajaran, tahap-tahap dalam kegiatan pembelajaran, lingkungan pembelajaran, dan pengelolaan kelas (Arends dalam Trianto 2010). Sedangkan menurut Joyce \& Weil dalam (Sumantri and Permana 2001) model pembelajaran adalah kerangka konseptual yang melukiskan prosedur yang sistematis dalam mengorganisasikan pengalaman belajar untuk mencapai tujuan pembelajaran tertentu, dan memiliki fungsi sebagai pedoman bagi para perancang pembelajaran dan para pengajar dalam merencanakan dan melaksanakan aktifitas belajar mengajar.

\section{Model Pembelajaran Berbasis Proyek}

1. Konsep/Definisi

Pembelajaran Berbasis Proyek (Project Based Learning $=$ PjBL) adalah metoda pembelajaran yang menggunakan proyek/kegiatan sebagai media. Peserta didik melakukan eksplorasi, penilaian, interpretasi, sintesis, dan informasi untuk menghasilkan berbagai bentuk hasil belajar.

Pembelajaran Berbasis Proyek merupakan metode belajar yang menggunakan masalah sebagai langkah awal dalam mengumpulkan dan mengintegrasikan pengetahuan baru berdasarkan pengalamannya dalam beraktifitas secara nyata. Pembelajaran Berbasis Proyek memiliki karakteristik sebagai berikut:

a. peserta didik membuat keputusan tentang sebuah kerangka kerja;

b. adanya permasalahan atau tantangan yang diajukan kepada peserta didik;

c. peserta didik mendesain proses untuk menentukan solusi atas permasalahan atau tantangan yang diajukan;

d. peserta didik secara kolaboratif bertanggungjawab untuk mengakses dan mengelola informasi untuk memecahkan permasalahan;

e. proses evaluasi dijalankan secara kontinyu;

f. peserta didik secara berkala melakukan refleksi atas aktivitas yang sudah dijalankan;

g. produk akhir aktivitas belajar akan dievaluasi secara kualitatif; dan 


Kredo 4 (2021)
KREDO: Jurnal Ilmiah Bahasa dan Sastra
Terakreditasi Sinta 4 berdasarkan Keputusan
Direktorat Jenderal Penguatan Riset dan
Pengembangan, Kementerian Riset, Teknologi dan
Pendidikan Tinggi Republik Indonesia
Nomor: 23/E/KPT/2019. 08 Agustus 2019
https://jurnal.umk.ac.id/index.php/kredo/index

situasi pembelajaran sangat toleran terhadap kesalahan dan perubahan.

\section{Teks Eksposisi}

a. Pengertian Teks Eksposisi

Pengertian teks eksposisi adalah paragraf atau karangan yang terkandung sejumlah informasi dan pengetahuan yang disajikan secara singkat, padat, dan akurat. Paragraf eksposisi ini bersifat Ilmiah atau dapat dikatakan nonfiksi (Amassang 2018).

Eksposisi adalah salah satu jenis pengembangan paragraf dalam penulisan yang di mana isinya ditulis dengan tujuan untuk menjelaskan atau memberikan pengertian dengan gaya penulisan yang singkat, akurat, dan padat.

b. Tujuan Teks Eksposisi

Tujuan teks eksposisi adalah untuk memaparkan atau menjelaskan infomasiinformasi tertentu sehingga pengetahuan para pembaca bertambah (Kurniati 2019).

c. Ciri-Ciri Teks Eksposisi

Tarigan (2008) memberikan penjelasan mengenai beberapa ciri-ciri teks eksposisi sebagai berikut;
1) Menjelaskan informasi-informasi pengetahuan
2) Gaya informasi yang mengajak
3) Penyampaian secara lugas dan menggunakan bahasa yang baku

4) Tidak memihak artinya tidak memaksakan kemauan penulis terhadap pembaca

5) Fakta dibakai sebagai alat kontribusi dan alat kontritasi

d. Struktur Teks Eksposisi

1) Tesis (Pembukaan)

2) Argumentasi (Isi)

3) Penegasan ulang (Penegasan ulang)

\section{METODE PENELITIAN}

\section{A. Jenis Penelitian}

Penelitian ini merupakan Penelitian kuantitatif dengan menggunakan metode Eksperimen. Penelitian ini dilaksanakan dalam bentuk pembelajaran kegiatan pembelajran. Dikatakan penelitian kuantitatif karena dalam pengumpulan data menggunakan angka-angka.

\section{B. Variabel dan Desain penelitian}

a. Variabel Penelitian

$$
\text { Variabel yang diamati dalam }
$$
penelitian ini, yaitu pembelajaran berbasis proyek dalam menulis teks eksposisi siswa kelas XI SMK Muhammadiyah 3 Makassar.

b. Desain Penelitian

Desain atau model penelitian yang digunakan dalam penelitian ini adalah desain penelitian yang bersifat eksperimen. Penelitian ini merupakan penelitian eksperimen dan dilakukan sebanyak 4 kali petemuan, yaitu observasi, proses (sebelum eksperimen), 


Kredo 4 (2021)
KREDO: Jurnal Ilmiah Bahasa dan Sastra
Terakreditasi Sinta 4 berdasarkan Keputusan
Direktorat Jenderal Penguatan Riset dan
Pengembangan, Kementerian Riset, Teknologi dan
Pendidikan Tinggi Republik Indonesia
Nomor: 23/E/KPT/2019. 08 Agustus 2019
https://jurnal.umk.ac.id/index.php/kredo/index

tindakan dan kegiatan proses (setelah eksperimen) dengan memfokuskan satu kelas sebagai sampel.

\section{Populasi dan Sampel Penelitian \\ 1. Populasi}

Populasi penelitian ini adalah keseluruhan siswa kelas XI SMK Muhammadiyah 3 Makassar. Populasi penelitian ini ditetapkan pada kelas XI yang terdiri dari empat kelas yaitu, kelas administrasi perkantoran, keperawatan, akuntansi, tehnik komputer dan jaringan. Gambaran kondisi populasi penelitian seperti pada tabel berikut;

Tabel 1. Kondisi Populasi Penelitian

\begin{tabular}{cccc}
\hline \multirow{2}{*}{ NO } & \multirow{2}{*}{ KELAS } & \multicolumn{2}{c}{ JENIS KELAMIN } \\
\cline { 3 - 4 } & & L & P \\
\hline 1 & KPW & 0 & 14 \\
2 & ADM & 1 & 20 \\
3 & AK & 10 & 27 \\
4 & TKJ & 12 & 15 \\
\hline & JUMLAH & & 99 \\
\hline
\end{tabular}

\section{Sampel}

Sampel yang ditetapkan dalam penelitian ini adalah seluruh siswa kelas XI SMK Muhammadiyah 3 Makassar, khususnya siswa kelas keperawatan (KPW) yang berjumlah 14 siswa Tabel 2. Kondisi Sampel Penelitian

\begin{tabular}{cccc}
\hline \multirow{2}{*}{ NO } & \multicolumn{2}{c}{ JENIS KELAMIN } & \multirow{2}{*}{ JUMLAH } \\
\cline { 2 - 3 } & $\mathbf{L}$ & $\mathbf{P}$ & \\
\hline 1 & 0 & 14 & 14 \\
\hline
\end{tabular}

\section{Definisi Operasional Variabel}

Definisi operasional variabel dimaksudkan untuk memperjelas batasan pemahaman terhadap variabel yang diteliti sehingga tidak terjadi bias makna. Adapun istilah dari variabel yang didefinisikan tersebut yaitu;

a. Pembelajaran berbasis proyek merupakan metode belajar yang memberikan suatu proyek atau pekerjkaan tertentu kepada siswa untuk dikerjakan sehingga siswa memiliki pemahaman tertentu sebagaimana yang diharapkan.

b. Kemampuan menulis merupakan daya atau kesanggupan siswa dalam mencipta tulisan yang bermutu.

\section{E. Teknik Pengumpulan Data}

Teknik yang digunakan untuk mengumpulkan data penelitian ini adalah teknik tes, yaitu tes menulis teks eksposisi. Pembelajaran dilaksanakan selama 4 kali petemuan. Pertemuan petama dan kedua sebagai observasi dan pretes. Pertemuan ketiga treatmen (tindakan) pertemuan keempat proses. Setiap pertemuan dilakukan dalam waktu 2 x 45 menit. Waktu yang digunakan tersebut disesuaikan dengan jam pelajaran bahasa Indonesia di sekolah bersangkutan. Adapun prosedur penelitian yaitu; kegiatan awal (pretest), observasi, dan kegiatan akhir. 


Kredo 4 (2021)
KREDO: Jurnal Ilmiah Bahasa dan Sastra
Terakreditasi Sinta 4 berdasarkan Keputusan
Direktorat Jenderal Penguatan Riset dan
Pengembangan, Kementerian Riset, Teknologi dan
Pendidikan Tinggi Republik Indonesia
Nomor: 23/E/KPT/2019. 08 Agustus 2019
https://jurnal.umk.ac.id/index.php/kredo/index

\section{F. Teknik Analis Data}

Data yang terkumpul dalam penelitian ini dianalisis dengan menggunakan teknik statistik deskiptif. Data yang diperoleh dari hasil penelitian melalui instrumen akan diolah dan dianalisis. Data ini digunakan untuk menguji hipotesis, di sinilah akan diketahui apakah hipotesis dapat diterima atau ditolak.

1. Statistik deskriptif

a. Mencari mean rata-rata, dengan menggunakan rumus:

$\mathrm{Xi}=60 \%$ skor maksimal

Keterangan: $=$ mean ideal

b. Mengukur penyebaran dengan rumus:

$\mathrm{Si}=1 / 4 \times \mathrm{Xi}$

Keterangan:

$\mathrm{Si}=$ simpangan baku ideal

$\mathrm{Xi}=$ mean ideal

2. Adapun langkah-langkah analisis data sebagai berikut:

a. Membuat data skor

Skor mentah yang ditetapkan berdasarkan aspek yang dinilai dari menulis teks eksposisi. Model penilaian dalam penelitian ini adalah penilaian analitik dengan skala penilaian 1-100. Jadi, skor maksimal tes menulis teks eksposisi adalah 100 dengan kriteria penilaian sebagai berikut:

1) kesesuaian isi yakni kesesuaian antara isi teks dengan topik yang diperdebatkan, skor penilaian sebagai berikut: menarik dibaca, alur berpikirnya baik, memaparkan topik yang diperdebatkan (nilai 25-30);

a) Teksnya menarik dibaca, alur berpikirnya baik, kurang mampu memaparkan topik yang diperdebatkan (nilai 19-24);

b) Pengembangan kurang relevan dengan topik yang diperdebatkan (nilai 13-18);

c) Karangannya kurang menarik, alur berpikirnya kurang baik, kurang mampu memaparkan topik yang diperdebatkan (nilai 7-12); dan

d) Isi teksnya sama sekali tidak bersifat eksposisi (nilai 1-6).

2) Organisasi karangan, skor penilaian 20 dengan alternatif.

a) paragraf tersusun rapi, pemakaian topik karakter baik, organisasi meyakinkan, skor karangan mudah diikuti (nilai 13-16).

b) Ada usaha menyusun paragraf, tidak jelas dan kurang memberikan kesan (nilai 9- 13).

c) Urutan paragraf sulit diikuti, sulit dipahami (nilai 5-8).

d) Paragraf tidak terencana (nilai 1-4).

3) Penggunaan bahasa (kalimat efektif), skor penilaian 20 dengan alternatif nilai:

a) kalimat yang digunakan lancar, cermat, meskipun sedikit terdapat kesalahan tata bahasa (nilai 17-20). 


Kredo 4 (2021)
KREDO: Jurnal Ilmiah Bahasa dan Sastra
Terakreditasi Sinta 4 berdasarkan Keputusan
Direktorat Jenderal Penguatan Riset dan
Pengembangan, Kementerian Riset, Teknologi dan
Pendidikan Tinggi Republik Indonesia
Nomor: 23/E/KPT/2019.08 Agustus 2019
https://jurnal.umk.ac.id/index.php/kredo/index

b) Kalimat lancar, cermat, tetapi ada kesalahan tata bahasa menyebabkan kalimat tidak gramatikal (9-12),

c) Ada beberapa kalimat yang kurang dipahami (1-4).

4) Pemilihan kata (diksi), yakni kemampuan siswa memilih kata yang tepat dan benar didalam kalimat. Skor penilaian 20 dengan indikasi sebagai berikut:

a) Pemakaian kata lancar, tepat, diksinya memengaruhi pada kesuksesan berdasarkan topik yang diperdebatkan (nilai 17-30),

b) Kata yang digunakan jelas, tetapi kurang tepat penggunaannya. Banyak kata bermakna ganda (nilai 5-8), dan

c) Pemakaian kata tidak tepat, bentuk kata smua salah (nilai 1-4).

5) Penggunaan ejaan dan tanda baca, skor penilaiannya 10 dengan alternatif nilai sebagai berikut:

a) Pemakaian ejaan dan tanda baca, penulisan kata, penulisan huruf, penulisan kata depan, penulisan suku kata semua benar (nilai 9-10),

b) Ada kesalahan ejaan dan tanda baca (nilai 7-8),

c) Banyak kesalahan penggunaan ejaan dan tanda baca, tetapi masih dapat dipahami (nilai 5-6),

d) Kesalahan ejaan dan tanda baca banyak sekali (nilai 3-4), e) Penggunaan tanda baca serba salah (nilai 1-2).

Untuk mengetahui seberapa efektifnya model pembelajaran berbasis proyek dalam menulis teks eksposisi siswa maka dapat digambarkan dengan rumus sebagai berikut:

$$
\left(\mathrm{O}_{2}-\mathrm{O}_{1}\right)=\left(\mathrm{O}_{4}-\mathrm{O}_{3}\right)
$$

Keterangan:

$\mathrm{O}_{1}=$ Pretes kelompok eksperimen

$\mathrm{O}_{2}=$ Pretes kelompok kontrol

$\mathrm{O}_{3}=$ Hasil belajar siswa setelah diberikan perlakuan (eksperimen) $\mathrm{O}_{4}=$ Hasil belajar siswa yang tidak diberikan perlakuan (kontrol).

b. Uji Inferensial

Teknik analisis data ini digunakan untuk menarik kesimpulan tentang sampel yang ditarik dari populasinya. Pengujian yang digunakan adalah uji signifikan (uji t) dengan langkahlangkah sebagai berikut:

1) Membuat tabel penolong untuk mencari nilai $\mathrm{t}$

2) Menghitung nilai mean dari perbedaan preetesst dan posttest, dengan, digunakan teknik statistik $\mathrm{t}$ (uji-t) sebagai berikut:

a) Mencari " $M d$ " dengan menggunakan rumus:

$$
M d=\frac{\sum d}{N}
$$

\section{3 | Jurnal Kredo} Vol. 4 No. 22021 


Kredo 4 (2021)
KREDO: Jurnal Ilmiah Bahasa dan Sastra
Terakreditasi Sinta 4 berdasarkan Keputusan
Direktorat Jenderal Penguatan Riset dan
Pengembangan, Kementerian Riset, Teknologi dan
Pendidikan Tinggi Republik Indonesia
Nomor: 23/E/KPT/2019. 08 Agustus 2019
https://jurnal.umk.ac.id/index.php/kredo/index

Keterangan:

$M d \quad=$ Mean dari perbedaan pree test dan post test

$\sum d \quad=$ jumlah deviasi

$N \quad=$ Subjek pada sampel

b) Mencari harga " $\Sigma X^{2} d "$ dengan

menggunakan rumus:

$$
\sum X^{2} d=\sum d^{2} \frac{(\Sigma d)^{2}}{N}
$$

Keterangan:

$\sum X^{2} d=$ Jumlah kuadrat deviasi

$d^{2} \quad=$ Deviasi kuadrat

$N \quad=$ Subjek pada sampel

c) Menentukan harga $t$ dengan menggunakan rumus:

$$
t=\frac{M d}{\sqrt{\frac{\sum x^{2} d}{N(N-1)}}}
$$

Keterangan:

$M d \quad=$ Mean dari perbedaan pree test dan post test

$X d \quad=$ Deviasi masing-masing subjek

$\sum X^{2} d=$ Jumlah kuadrat deviasi

$N \quad=$ Subjek pada sampel

d) Menentukan aturan pengambilan keputusan atau kriteria yang signifikan dalam kaidah pengujian signifikan:
Jika $\mathrm{t}_{\text {hitung }}<\mathrm{t}$ tabel Maka $\mathrm{H}_{0}$ diterima Jika $\mathrm{t}_{\text {hitung }}>\mathrm{t}$ tabel $\mathrm{Maka}_{1}$ diterima

e) Menentukan harga $t_{\text {table }}$

Mencari $t$ table dengan menggunakan table distribusi $\mathrm{t}$ dengan taraf signifikan $\alpha=0,05$ dan $d b=N-1$

f) Membuat kesimpulan apakah strategi belajar MURDER efektif dalam peningkatan hasil belajar matematika.

\section{HASIL DAN PEMBAHASAN}

\section{HASIL}

\section{A. Analisis Deskriptif Hasil Observasi Kegiatan Belajar Siswa}

Tabel 3. Keaktifan siswa pada kelas kontrol

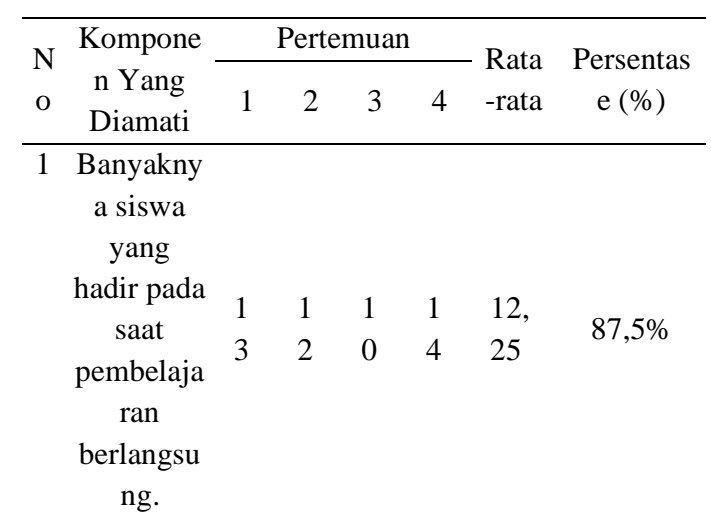




Kredo 4 (2021)
KREDO: Jurnal Ilmiah Bahasa dan Sastra
Terakreditasi Sinta 4 berdasarkan Keputusan
Direktorat Jenderal Penguatan Riset dan
Pengembangan, Kementerian Riset, Teknologi dan
Pendidikan Tinggi Republik Indonesia
Nomor: 23/E/KPT/2019.08 Agustus 2019
https://jurnal.umk.ac.id/index.php/kredo/index

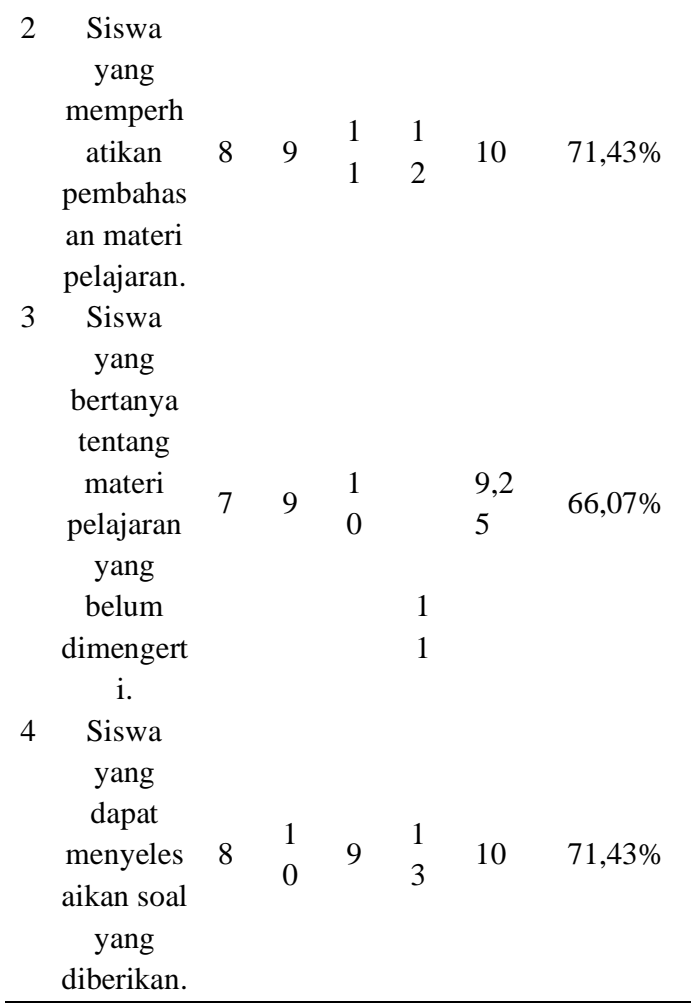

Tabel 4. Keaktifan siswa pada kelas eksperimen

\begin{tabular}{|c|c|c|c|c|c|c|c|}
\hline \multirow{2}{*}{$\begin{array}{l}\mathrm{N} \\
\mathrm{O}\end{array}$} & \multirow{2}{*}{$\begin{array}{c}\text { Kompon } \\
\text { en Yang } \\
\text { Diamati }\end{array}$} & \multicolumn{4}{|c|}{ Pertemuan } & \multirow{2}{*}{$\begin{array}{c}\text { Rata- } \\
\text { rata }\end{array}$} & \multirow{2}{*}{$\begin{array}{c}\text { Persenta } \\
\text { se }(\%)\end{array}$} \\
\hline & & 1 & 2 & 3 & 4 & & \\
\hline 1 & $\begin{array}{l}\text { Banyak } \\
\text { nya } \\
\text { siswa } \\
\text { yang } \\
\text { hadir } \\
\text { pada } \\
\text { saat } \\
\text { pembel } \\
\text { ajaran } \\
\text { berlang } \\
\text { sung. }\end{array}$ & $\begin{array}{l}1 \\
3\end{array}$ & $\begin{array}{l}1 \\
4\end{array}$ & $\begin{array}{l}1 \\
4\end{array}$ & $\begin{array}{l}1 \\
4\end{array}$ & $\begin{array}{l}13 \\
75\end{array}$ & $\begin{array}{l}98,21 \\
\%\end{array}$ \\
\hline
\end{tabular}

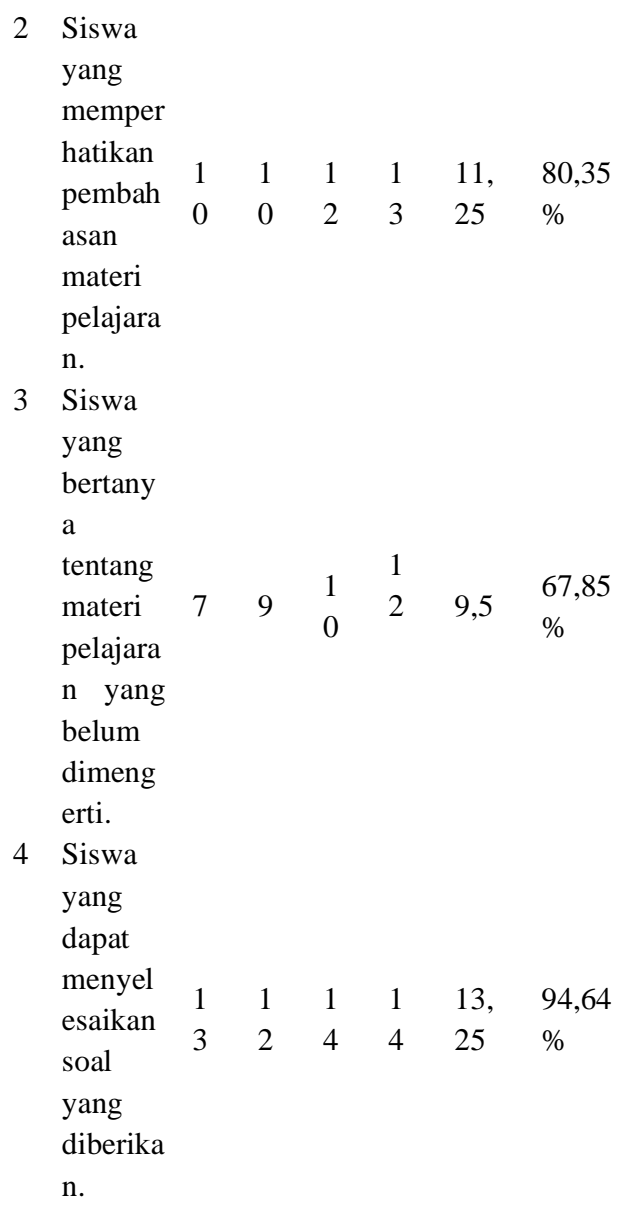

\section{B. Analisis Deskriptif hasil Belajar Teks Eksposisi Siswa}

Tabel.5 deskriptif hasil belajar menulis teks ekposisi siswa kelas kontrol

\begin{tabular}{ccccc}
\hline \multirow{2}{*}{ Statistik } & \multicolumn{4}{c}{ Nilai statistik } \\
\cline { 2 - 5 } & \multicolumn{2}{c}{ Pretest } & \multicolumn{2}{c}{ Postest } \\
\cline { 2 - 5 } & $\begin{array}{c}\text { Ekperi } \\
\text { men }\end{array}$ & $\begin{array}{c}\text { Kontr } \\
\text { ol }\end{array}$ & $\begin{array}{c}\text { Ekperi } \\
\text { men }\end{array}$ & $\begin{array}{c}\text { Kontr } \\
\text { ol }\end{array}$ \\
\hline Jumlah & 6 & 6 & 6 & 6 \\
sampel & & & & \\
Nilai & 75 & 75 & 85 & 80 \\
tertinggi & & & &
\end{tabular}




Kredo 4 (2021)
KREDO: Jurnal Ilmiah Bahasa dan Sastra
Terakreditasi Sinta 4 berdasarkan Keputusan
Direktorat Jenderal Penguatan Riset dan
Pengembangan, Kementerian Riset, Teknologi dan
Pendidikan Tinggi Republik Indonesia
Nomor: 23/E/KPT/2019.08 Agustus 2019
https://jurnal.umk.ac.id/index.php/kredo/index

\begin{tabular}{ccccc} 
Nilai & 60 & 60 & 77 & 65 \\
terendah \\
$\begin{array}{c}\text { Nilai rata- } \\
\text { rata(x) }\end{array}$ & 66,66 & 65,83 & 81 & 73,33 \\
$\begin{array}{c}\text { Standar } \\
\text { deviasi } \\
\text { (SD) }\end{array}$ & 19,45 & 6,64 & 2,68 & 6,05 \\
\hline
\end{tabular}

Berdasarkan tabel di atas, dapat diketahui bahwa pada prites kelas eksperimen dengan jumlah 6 siswa yang menjadi sampel, siswa yang memiliki nilai tertinggi 75 , nilai terendah 60 dengan nilai rata-rata 66,66 dan standar deviasi 19,45 untuk kelas kontrol dengan jumlah sampel 6 penelitian, siswa yang memiliki nilai tertinggi 75 , nilai terendah 60 nilai rata-rata 65,83 dan standar deviasi 6,64 ini berarti bahwa nilai pada kelas kontrol sifatnya homogen dari pada kelas eksperimen. Postes untuk kelas eksperimen yaitu nilai tertinggi 85 , sifat terendah 77 , nilai rata-rata 81 dengan standar deviasi 2,68. Sedangkan kelas kontrol nilai tertinggi 80 , nilai terendah 65 , dan nilai rata-rata 73,33 dengan standar deviasi 6,05. Hal ini menandakan bahwa homogenitas pada kelas eksperimen.

Untuk mengetahui seberapa efektifnya model pembelajaran berbasis proyek dalam menulis teks eksposisi siswa maka dapat digambarkan dengan rumus

$$
\left(0_{2}-0_{1}\right)-\left(0_{4}-0_{3}\right)
$$

Keterangan

$0_{1}=$ pretes kelompok eksperimen

$\mathrm{O}_{2}=$ pretes kelopok kontrol
$0_{3}=$ hasil belajar siswa stelah deberikan perlakuan (ekperimen)

$0_{4}=$ hasil belajar siswa yang tidak diberikan perlakuan (kontrol)

Tabel 6 nilai rata-rata pretes dan postes kelas eksperimen dan kelas kontrol

\begin{tabular}{|c|c|c|c|c|}
\hline \multirow[b]{3}{*}{ Statistik } & \multicolumn{4}{|c|}{ Nilai statistik } \\
\hline & \multicolumn{2}{|c|}{ Pretes } & \multicolumn{2}{|c|}{ Postes } \\
\hline & $\begin{array}{c}\text { Ekperim } \\
\text { en } \\
0,1\end{array}$ & $\begin{array}{c}\text { Kontro } \\
\mathbf{1} \\
\mathbf{0 , 3}\end{array}$ & $\begin{array}{c}\text { Ekperim } \\
\text { en } \\
0,2\end{array}$ & $\begin{array}{c}\text { Kontro } \\
1 \\
\mathbf{0 , 4}\end{array}$ \\
\hline $\begin{array}{l}\text { Nilai rata- } \\
\operatorname{rata}(x)\end{array}$ & 66,66 & 65,83 & 81 & 73,33 \\
\hline
\end{tabular}

Hasil analisis data tahun 2018

Kelas eksperimen $\quad=0_{2}-0_{1}$

$$
\begin{aligned}
& =81-6,66 \\
& =14,34
\end{aligned}
$$

Kelas kontrol $\quad=0_{4}-0_{3}$

$$
\begin{aligned}
& =73,33-65,83 \\
& =7,5
\end{aligned}
$$

Efektivitas perlakuan $=0_{2}-0_{1}-0_{4}-0_{3}$

$$
\begin{aligned}
& =14,34-7,5 \\
& =6,84
\end{aligned}
$$

Efek pembelajaran berbasis proyek $=$ 6,84

Hasil analisis di atas menunjukan selisih antara nilai pretes dengan postes pada kelas kontrol dan kelas eksperimen yaitu $\left(0_{2}\right)-\left(0_{1}\right)-\left(0_{4}\right)-\left(0_{3}\right)$ atau 14,34 $-7,5=6,84$, sehingga dari nilai ini kita mendapatkan gambaran bahwa model pembelajaran berbasis proyek memiliki tingkat efektifitas yang positif terhadap hasil belajar menulis teks eksposisi siswa kelas XI SMK Muhammadiyah 3 Makassar. 


Kredo 4 (2021)
KREDO: Jurnal Ilmiah Bahasa dan Sastra
Terakreditasi Sinta 4 berdasarkan Keputusan
Direktorat Jenderal Penguatan Riset dan
Pengembangan, Kementerian Riset, Teknologi dan
Pendidikan Tinggi Republik Indonesia
Nomor: 23/E/KPT/2019. 08 Agustus 2019
https://jurnal.umk.ac.id/index.php/kredo/index

\section{Tingkat ketuntasan belajar siswa pada kelas kontol dan kelas eksperimen}

1. Ketuntasan belajar kelas eksperimen

Apabila hasil belajar siswa pada kelas eksperimen dianalisis, maka presentasi ketuntasan belajar siswa dapat di lihat pada tabel 7 di bawah ini

Tabel 7 deskripsi ketuntasan belajar siswa pada kelas kontrol

\begin{tabular}{|c|c|c|c|}
\hline $\begin{array}{l}\text { Persentase } \\
\text { skor }\end{array}$ & Kategori & Frekuensi & $\begin{array}{c}\text { Persentase } \\
(\%)\end{array}$ \\
\hline $0 \%-69 \%$ & $\begin{array}{l}\text { Tidak } \\
\text { tuntas }\end{array}$ & 4 & $66,6 \%$ \\
\hline $\begin{array}{c}70 \%-100 \\
\%\end{array}$ & Tuntas & 2 & $33,4 \%$ \\
\hline \multicolumn{2}{|c|}{ Jumlah } & 6 & $100,00 \%$ \\
\hline
\end{tabular}

Hasil analisis data tahun 2018

Berdasarkan tabel di atas, dapat dilihat bahwa 0 atau $0 \%$ persentase siswa yang tidak tuntas dan 6 atau 100\% siswa yang tuntas.

2. Ketuntasan belajar kelas eksperimen

Apabila hasil belajar siswa pada kelas kontrol dianalisis maka persentase ketuntasan belajar siswa dapat dilihat pada tabel 8 di bawah ini.

Tabel 8. Deskriptif ketuntasan belajar siswa pada kelas kontrol

\begin{tabular}{llll}
\hline $\begin{array}{l}\text { Persentase } \\
\text { skor }\end{array}$ & Kategori & Frekuensi & $\begin{array}{l}\text { Persentase } \\
(\%)\end{array}$ \\
\hline $0 \%-69 \%$ & $\begin{array}{l}\text { Tidak } \\
\text { tuntas }\end{array}$ & 0 & $0 \%$ \\
\hline $70 \%-100$ & Tuntas & 6 & $100 \%$ \\
\hline
\end{tabular}

397 | Jurnal Kredo Vol. 4 No. 22021

\begin{tabular}{ccc}
\hline Jumlah & 6 & $100 \%$ \\
\hline Sesuai & dengan hipotesis yakni
\end{tabular}
pembelajaran berbasis proyek dalam menulis teks eksposisi sangat efektif", maka teknik yang digunakan untuk menguji hipotesis tersebut adalah teknik statistik t (uji-t).

Tabel 9 Analisis skor pretest dan post test

\begin{tabular}{lcccc}
\hline No. & $\begin{array}{c}\mathbf{X}_{\mathbf{1}} \\
\text { (pretest) }\end{array}$ & $\begin{array}{c}\mathbf{X}_{\mathbf{2}} \\
\text { (posttest) }\end{array}$ & $\begin{array}{c}\mathbf{d =} \mathbf{X}_{\mathbf{2}} \\
-\mathbf{X}_{\mathbf{1}}\end{array}$ & $\mathbf{d}^{\mathbf{2}}$ \\
\hline 1. & 60 & 80 & 20 & 400 \\
2. & 70 & 85 & 15 & 225 \\
3. & 65 & 95 & 30 & 90 \\
4. & 65 & 92 & 27 & 729 \\
5. & 68 & 90 & 22 & 484 \\
6. & 70 & 85 & 15 & 225 \\
7. & 60 & 65 & 5 & 25 \\
8. & 50 & 85 & 35 & 1225 \\
9. & 55 & 60 & 5 & 25 \\
10. & 65 & 75 & 10 & 100 \\
11. & 65 & 95 & 30 & 900 \\
12. & 65 & 95 & 30 & 900 \\
13. & 50 & 70 & 20 & 400 \\
14 & 60 & 95 & 35 & 1225 \\
\hline Jumlah & $\mathbf{8 6 8}$ & $\mathbf{1 0 7 7}$ & $\mathbf{2 9 9}$ & $\mathbf{6 9 5 3}$ \\
\hline
\end{tabular}

$$
\text { Selanjutnya menguji hipotesis }
$$

dengan langkah-langkah sebagai berikut:

a. Mencari harga " $M d$ " dengan menggunakan rumus:

$$
\begin{aligned}
M d & =\frac{\sum d}{N} \\
& =\frac{299}{14} \\
& =21.35
\end{aligned}
$$

b. Mencari harga " $\sum X^{2} d "$ dengan menggunakan rumus: 


Kredo 4 (2021)
KREDO: Jurnal Ilmiah Bahasa dan Sastra
Terakreditasi Sinta 4 berdasarkan Keputusan
Direktorat Jenderal Penguatan Riset dan
Pengembangan, Kementerian Riset, Teknologi dan
Pendidikan Tinggi Republik Indonesia
Nomor: 23/E/KPT/2019.08 Agustus 2019
https://jurnal.umk.ac.id/index.php/kredo/index

$$
\begin{aligned}
\sum X^{2} d & =\sum d^{2} \frac{\left(\sum d\right)^{2}}{N} \\
& =6953-\frac{(299)^{2}}{15} \\
& =6953-6385 \\
& =568
\end{aligned}
$$

c. Menentukan harga $t_{\text {Hitung }}$

$$
\begin{aligned}
t & =\frac{M d}{\sqrt{\frac{\sum x^{2} d}{N(N-1)}}} \\
& =\frac{21.35}{\sqrt{\frac{568}{14(14-1)}}} \\
& =\frac{568}{14(13)} \\
& =\frac{21.35}{\sqrt{\frac{568}{183}}} \\
& \frac{21.35}{1,76} \\
& =12.13
\end{aligned}
$$

d. Menentukan aturan pengambilan keputusan atau kriteria yang signifikan.

Kaidah pengujian signifikan:

Jika $\mathrm{t}_{\text {hitung }} \leq \mathrm{t}$ tabel Maka $\mathrm{H}_{0}$ diterima

Jika $\mathrm{t}_{\text {hitung }}>\mathrm{t}$ tabel Maka $\mathrm{H}_{1}$ ditolak

e. Menentukan harga $t$ Tabel

Mencari $t_{\text {Tabel }}$ dengan menggunakan tabel distribusi t dengan taraf signifikan

$$
\begin{aligned}
& \alpha=0,05, \text { dan } d b=N-1 \\
& \begin{aligned}
\alpha=5 \% & =0,05 \\
d b & =N-1 \\
& =14-1 \\
& =13 \\
t_{0,95(38)} & =1,68
\end{aligned}
\end{aligned}
$$

f. Kesimpulan

Setelah menentukan $\mathrm{t}$ Hitung $=18,86$

$>\mathrm{t}_{\text {tabel }}=(18,86>1,68)$ maka dapat

disimpulkan bahwa $\mathrm{H}_{1}$ diterima dan $\mathrm{H}_{0}$ ditolak.

Dari hasil penelitian di atas penulis dapat simpulkan bahwa hipotesis dalam penelitian ini diterima karena keefektifan model pembelajaran berbasis proyek dalam menulis teks eksposisi siswa kelas XI SMK Muhammadiyah Makassar sangat efektif.

\section{PEMBAHASAN}

Penelitian ini adalah desain penelitian yang bersifat eksperimen, peneliti membandingkan dua kelas, salah satu kelas diajar dengan model pembelajaran berbasis proyek sedangkan kelas-kelas yang diajar dengan menggunakan metode pembelajaran konfesional yaitu metode ceramah yang divariasikan dengan diskusi kelompok.

Sebelum diberikan perlakuan atau pembelajaran, kedua kelas yakni kelas eksperimen dan kelas kontrol, terlebih dahulu diberikan pretes untuk 


Kredo 4 (2021)
KREDO: Jurnal Ilmiah Bahasa dan Sastra
Terakreditasi Sinta 4 berdasarkan Keputusan
Direktorat Jenderal Penguatan Riset dan
Pengembangan, Kementerian Riset, Teknologi dan
Pendidikan Tinggi Republik Indonesia
Nomor: 23/E/KPT/2019.08 Agustus 2019
https://jurnal.umk.ac.id/index.php/kredo/index

mengetahui pengetahuan awal kedua kelas, dari hasil analisis deskriptif diketahui bahwa rata-rata hasil belajar menulis teks eksposisi kedua kelas hampir sama, hal ini menandakan bahwa kemampuan awal kedua kelas yaitu kelas XI KPW sebagai kelas eksperimen dan kelas XI Ap sebagai kelas kontrol, dengan kata lain kedua kelas bersifat homogen.

Setelah diberikan perlakuan, kembali kedua kelas diberikan postes untuk mengetahui efektifitas teknik model pembelajaran berbasis proyek terhadap hasil belajar menulis teks ekposisi siswa. Dari hasil analisis deskriptif diperoleh bahwa rata-rata hasil belajar menulis teks eksposisi yang diajar dengan model pembelajaran berbasis proyek lebih besar dibandingkan dengan hasil belajar menulis teks eksposisi siswa yang diajar dengan metode konfensional yang terdiri dari metode ceramah dan diskusis kelompok. The liang gie (2002: 45) berpendapat bahwa menulis adalah keseluruhan rangkaian kegiatan seseorang dalam memngungkapkan buah pikirannya melalui bahasa tulis untuk dibaca dan dimengerti oleh orang lain. Kegiatan menulis merupakan keterampilan menulis yang dapat dipahami dan dipelajari.

Eksposisi adalah paragraf atau karangan yang terkandung sejumlah informasi dan pengetahuan yang disajikan secara singkat, padat, dan akurat. Paragraf eksposisi ini bersifat ilmiah atau dapat dikatakan besifat nonfiksi. Eksposisi adalah salah satu jenis pengembangan paragraf dalam penulisan yang di mana isinya ditulis dengan tujuan untuk menjelaskan atau memberikan pengertian dengan gaya penulisan yang singkat akurat dan padat.

Peserta didik dapat meminta bantuan guru maupun teman sekelas untuk membantu dan mempertimbangkan gagasan yang dikemukakan. Pada tahap penyuntingan, peserta didik dilatih untuk memperbaiki aspek mekanik (ejaan, tanda baca, pilihan kata dan struktur kalimat) yang tidak sesuai dengan kaidah penulisan. Hal ini dilakukan untuk memperbaiki karangan sendiri maupun teman sekelas. Pada tahap publikasi, peserta didik menyampaikan tulisan kepada teman sekelas untuk meminta masukan guru dan teman sekelas agar mereka dapat berbagi agar tulisan menjadi sempurna.

Adanya perbedaan skor tersebut disebabkan karena dalam proses pembelajaran dengan model pembelajaran berbasis proyek, motivasi belajar siswa lebih tinggi dibandingkan dengan motivasi belajar siswa yang diajar dengan metode konvesional. Hal ini tercermin dari aktivitas siswa selama proses pembelajaran hampir seluruh 


Kredo 4 (2021)
KREDO: Jurnal Ilmiah Bahasa dan Sastra
Terakreditasi Sinta 4 berdasarkan Keputusan
Direktorat Jenderal Penguatan Riset dan
Pengembangan, Kementerian Riset, Teknologi dan
Pendidikan Tinggi Republik Indonesia
Nomor: 23/E/KPT/2019.08 Agustus 2019
https://jurnal.umk.ac.id/index.php/kredo/index

siswa aktif berdiskusi dan mencari jawaban atas soal-soal yang diberikan, sedangkan pada kelas kontrol pemberian materi dengan menggunakan metode konfesioanl.

Dari hasil belajar menulis teks ekposisi siswa yang diajar dengan menggunakan model pembelajaran berbasis proyek lebih tinggi apabila dibandingkan hasil belajar siswa dengan menggunakan metode ceramah dan diskusi kelompok (konvesional).

\section{SIMPULAN}

Berdasarkan hasil penelitian dapat disimpulkan bahwa proses kegiatan mengajar dengan menggunakan model berbasis proyek dapat meningkatkan hasil belajar menulis teks eksposisi siswa secara signifikan dibandingkan hasil belajar dengan menggunakan model pembelajaran konvensional di kelas XII SMK Muhammadiyah 3 Makassar dengan merujuk pada hasil analisis yang menunjukkan selisih antara pretest dengan postest pada kelas kontrol dan kelas eksperimen yaitu, $\left(\mathrm{O}_{2}-\mathrm{O}_{1}-\mathrm{O}_{4}-\mathrm{O}_{3}\right.$ ) atau $14,34-7,5=6,84$. Ketuntasan siswa pada kelas eksperimen yang diajar disebabkan karena dalam proses belajar yang menggunakan model pembelajaran berbasis proyek menekankan pada proses keaktifan siswa dalam proses belajar mengajar dalam menulis teks eksposisi.

\section{SARAN}

Berdasarkan hasil yang diperoleh dalam penelitian ini, maka penulis menyarankan:

1. Kepada pihak guru mata pelajaran Bahasa Indonesia agar memberikan bimbingan secara konprehensif kepada siswa selama kegiatan pembelajaran kompetensi menulis teks eksposisi.

2. Kepada pihak sekolah agar senantiasa mengadakan ontrol, pengawasan, bimbingan dan pengamatan yang sitematis, sehingga mendorong siswa agar belajar dengan dengan sungguhsungguh dengan penuh motivasi

3. Kepada pihak pemerintah agar menyediakan sarana dan prasarana dalam kegiatan proses belajar mengajar khususnya kegiatan menulis teks eksposisi

4. Kepada peneliti selanjutnya agar lebih mengembangkan penggunaan model pembelajaran berbasis proyek dalam menulis teks eksposisi 


Kredo 4 (2021)
KREDO: Jurnal Ilmiah Bahasa dan Sastra
Terakreditasi Sinta 4 berdasarkan Keputusan
Direktorat Jenderal Penguatan Riset dan
Pengembangan, Kementerian Riset, Teknologi dan
Pendidikan Tinggi Republik Indonesia
Nomor: 23/E/KPT/2019. 08 Agustus 2019
https://jurnal.umk.ac.id/index.php/kredo/index

\section{DAFTAR PUSTAKA}

Amassang, Dharma. 2018. Kemampuan Mengembangkan Gagasan Dalam Karangan Eksposisi Siswa Kelas X MIA 1 MAN 2 Palu. Jurnal Bahasa dan Sastra 3(4).

Dalman, Haji. 2021. Keterampilan Menulis. PT. Raja Grafindo Persada.

Djuroto, Totok, H Bambang Rahino Setokoesoemo, and Bambang Suprijadi. 2013. Menulis Artikel \& Karya Ilmiah. PT Remaja Rosdakarya.

Gie, Tha Liang. 2002. Terampil Mengarang. Yogyakarta: Andi.

Kurniati, Neni. 2019. Pengaruh Penguasaan Kosa Kata Dan Tata Bahasa Terhadap Kemampuan Menulis Teks Eksposisi. Diskursus: Jurnal Pendidikan Bahasa Indonesia 1(02): 195-200.

Martaulina, Sinta Diana. 2018. Bahasa Indonesia Terapan. Deepublish.

Noermanzah, Noermanzah. 2019. Bahasa Sebagai Alat Komunikasi, Citra Pikiran, dan Kepribadian. In Seminar Nasional Pendidikan Bahasa dan Sastra, 306-19.

Sumantri, Mulyani, and Johar Permana. 2001. Strategi Belajar Mengajar. Bandung: CV.

Tarigan, Henry Guntur. 2008. Menulis Sebagai Keterampilan Berbahasa. Bandung: Angkasa.

Trianto, M Pd. 2010. Mendesain Model Pembelajaran Inovatif-Progresif: Konsep, Landasan dan Implementasinya pada Kurikulum Tingkat Satuan Pendidikan (KTSP). Jakarta: Kencana.

Wicaksono, Andri, and Ahmad Subhan Roza. 2015. Teori Pembelajaran Bahasa: Suatu Catatan Singkat. Garudhawaca.

$401 \mid$ Jurnal Kredo

Vol. 4 No. 22021 